\title{
New geological map of the Thule region, North-West Greenland
}

\author{
Peter R. Dawes
}

Map sheet no. 5 (Thule), part of the 14-map geological map series at 1:500 000 covering the onshore geology of Greenland, was published in 1991 (Dawes 1991; Fig. 1). The Thule map covers the northern part of the west coast of Greenland between latitudes $75^{\circ} 15^{\prime}$ and $78^{\circ} \mathrm{N}$, including the region traditionally known as the Thule or Kap York district (Figs 1 \& 2). The southern part of the map covers the relatively inaccessible coast of Melville Bugt, known as the Lauge Koch Kyst. Here the Inland Ice reaches the sea along a broad front leaving land exposed only as nunataks, semi-nunataks, ice-rooted peninsulas and islands.

The name of the map is taken from the capital town and administrative centre of northern Greenland (Avanersuup Kommune), Thule or Qaanaaq, situated at $77^{\circ} 29^{\prime} \mathrm{N} 69^{\circ} 12^{\prime} \mathrm{W}$, about $100 \mathrm{~km}$ north of the wellknown communications centre of Thule Air Base, which is now also known by the Greenlandic name of Pituffik.

Apart from Quaternary deposits the Thule map depicts two main geological units: the Precambrian shield and the overlying Proterozoic Thule Basin (Fig. 3).

\section{GGU's field investigations}

The geological basis of the map is the field work carried out by the author during five summer seasons: 1971, 1974, 1975, 1978 and 1980. Early seasons were based on local Eskimo boat hire and foot traverses; later investigations were supported by GGU motor cutter $K . J . V$. Steenstrup, with limited helicopter charter out of Thule Air Base. Much of the Lauge Koch Kyst was surveyed by fixed-wing aircraft (De Havilland Twin Otter).

In 1978 Jan C. Escher (GGU) joined the author for several days mapping islands in western Melville Bugt, while Allen P. Nutman (then of Exeter University, U.K.) made a detailed study of the Qaqujârssuaq anorthosite and adjacent rocks at the head of Inglefield Bredning (Nutman, 1984). In 1980 Thomas Frisch (Geological Survey of Canada), who had mapped the Precambrian terrain of Ellesmere Island and Devon
Island on the opposite side of Baffin Bay (Fig. 2), participated in the field work, particularly the mapping of Melville Bugt (Frisch, 1981; Dawes \& Frisch, 1981).

\section{Geological compilation}

The description of field work above demonstrates that the Thule map is based on a primary reconnaissance survey in which the geological detail attained varies from area to area. The map thus stands in contrast with the other published GGU 1:500 000 sheets from northern Greenland - sheets 7 and 8 (Fig. 1) which are based on systematic field mapping by groups of two-man teams with fully airborne modern logistics operating from strategically placed field camps (Henriksen \& Higgins, 1991). The scarce resources available for detailed work on sheet 5 were concentrated on lithostratigraphic studies on the Thule Basin strata while detailed work on the crystalline basement was restricted to the 1:25000 mapping of the Qaqujârssuaq anorthosite body mentioned above (Nutman, 1984).

The source maps for the Thule compilation comprise 6 sheets covering the Thule Basin strata at a scale of 1:100 000 and 5 sheets at 1:200 000 of the surrounding crystalline terrane. These maps were compiled by the author from the field investigations mentioned above, as well as from extensive interpretation of aerial photographs. Published large-scale geological maps prior to the GGU field activity are restricted to just two areas around Thule Air Base, viz. 1:100 000 maps by Davies et al. (1963) and Fernald \& Horowitz (1964). Data from these maps has been incorporated in the Thule map sheet.

\section{Topographical base and revised ice margins}

The topographical base of the Thule map sheet is that of the 1:200 000 maps of the Geodetic Institute (published at 1:250 000; GI is now part of the Kort- og Matrikelstyrelsen - KMS). The map material was constructed from U.S. oblique aerial photography 1947-49, with some corrections from the 1950 s. 
However, the last 40 years have seen radical changes in the position of glaciers and the Inland Ice margin in North-West Greenland. The regional picture is one of continuous recession, although a single anomalous glacier at the head of Granville Fjord (Fig. 2) shows an advance of over $2 \mathrm{~km}$. In Melville Bugt the ice margin forms a wide shelf with some floating ice tongues and an ice front in places grounded on skerries. Since the aerial photography of the late 1940s, the ice wastage in this region has resulted in appreciable physiographic changes. New land has appeared in the form of islands and nunataks while previous nunataks and semi-nunataks have been released to become peninsulas and islands.

The total amount of retreat of the ice margin since 1947 to the present day varies throughout the map sheet: at the head of Inglefield Bredning it is more than $4 \mathrm{~km}$, in central Melville Bugt at Rink Gletscher it is up to $6 \mathrm{~km}$, while in southern Melville Bugt just south of $75^{\circ} \mathrm{N}$ there has been a retreat of more than $10 \mathrm{~km}$ across a broad front. Hand-drawn corrections to the maps necessarily had to be made concurrently with the field work. However, in order to portray the appreciable ice wastage consistently, a major revision of the ice margins throughout the map sheet has been undertaken based on aerial photography taken by the KMS in 1985. The position of the ice margin from these vertical 1:150 000 photographs was plotted visually onto copies of the 1:100 000 and 1:200 000 maps mentioned earlier.

\section{Precambrian geology}

The Thule map sheet covers the northern part of the Archaean block of western Greenland and the passage to the north into what is strongly surmised to be Proterozoic (Aphebian) crust. The late Proterozoic (Neohelikian-Hadrynian) Thule Basin overlies the eroded Precambrian shield covering the coastal part of the central Thule district (Figs $2 \& 3$ ).

\section{Precambrian shield}

The high-grade crystalline shield has been divided into five complexes: four of Archaean age and one of Early to Middle Proterozoic age (Fig. 4). The oldest isotopically dated rocks are gneisses of the Thule Mixed-gneiss Complex that have given a $\mathrm{Sm} / \mathrm{Nd}$ model age of 2910 Ma. Rock suites from both the Melville Bugt Orthogneiss Complex and the Kap York Metaigneous Complex have given $\mathrm{Rb} / \mathrm{Sr}$ errochron ages of about $2700 \mathrm{Ma}$ (Dawes et al., 1988). The Smithson Bjerge Magmatic Association of relatively small outcrop, which includes the Qaqujârssuaq anorthosite and

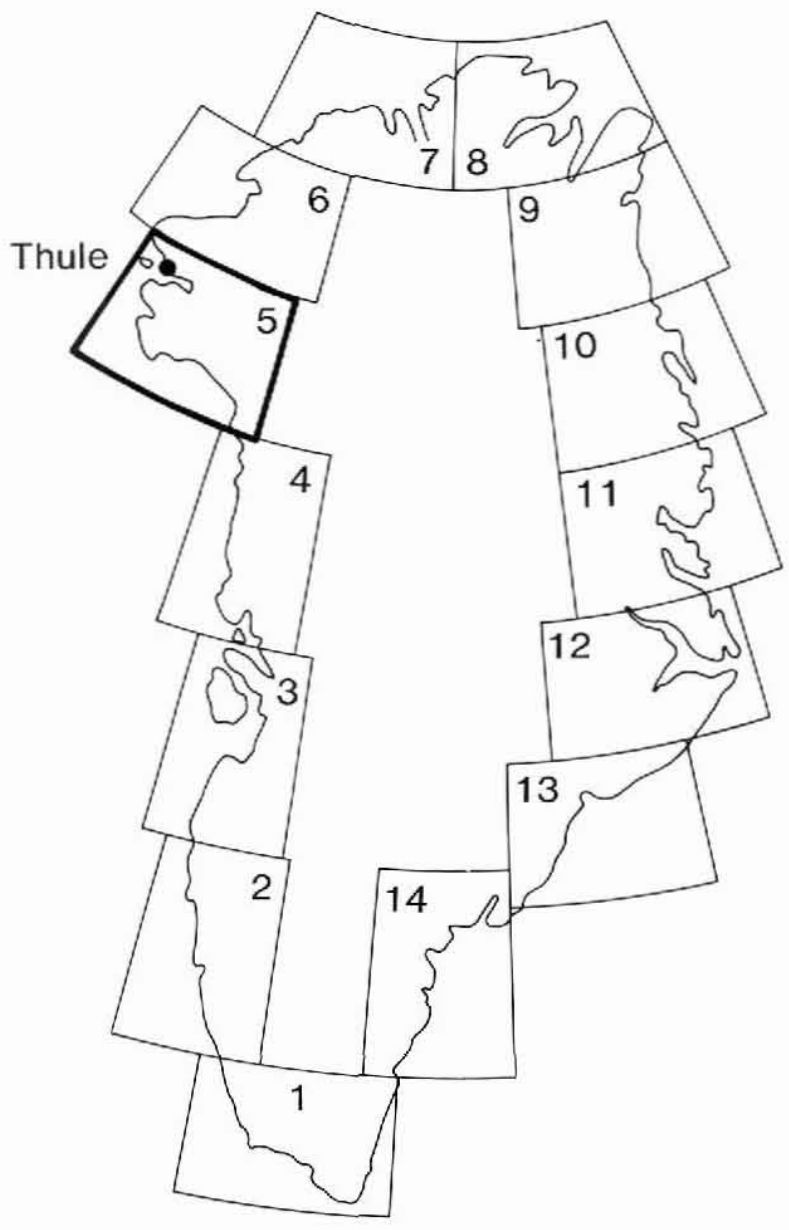

Fig. 1. Index map to the 1:500 000 geological map shcet coverage of Greenland published by GGU. Location of the Thule map is accentuated. Sheets $6.9,10 \& 11$ are not yet published.

a suite of granite-ferrodiorite rocks, has not been isotopically dated.

The Prudhoe Land Granulite Complex forms the northernmost crystalline rocks of the map sheet. These rather massive, granulite facies gneisses and granites are regarded as the southern extension of the Etah Metaigncous Complex of Inglefield Land that was emplaced after $2000 \mathrm{Ma}$.

Major areas of supracrustal rocks are distinguished within the Archaean gneiss complexes, as well as within the Prudhoe Land granulite facies granitoids. Field relationships suggest that both Archaean and Proterozoic supracrustal rocks occur. The entire region of the map sheet was affected by Hudsonian regional metamorphism (1850-1700 Ma). 


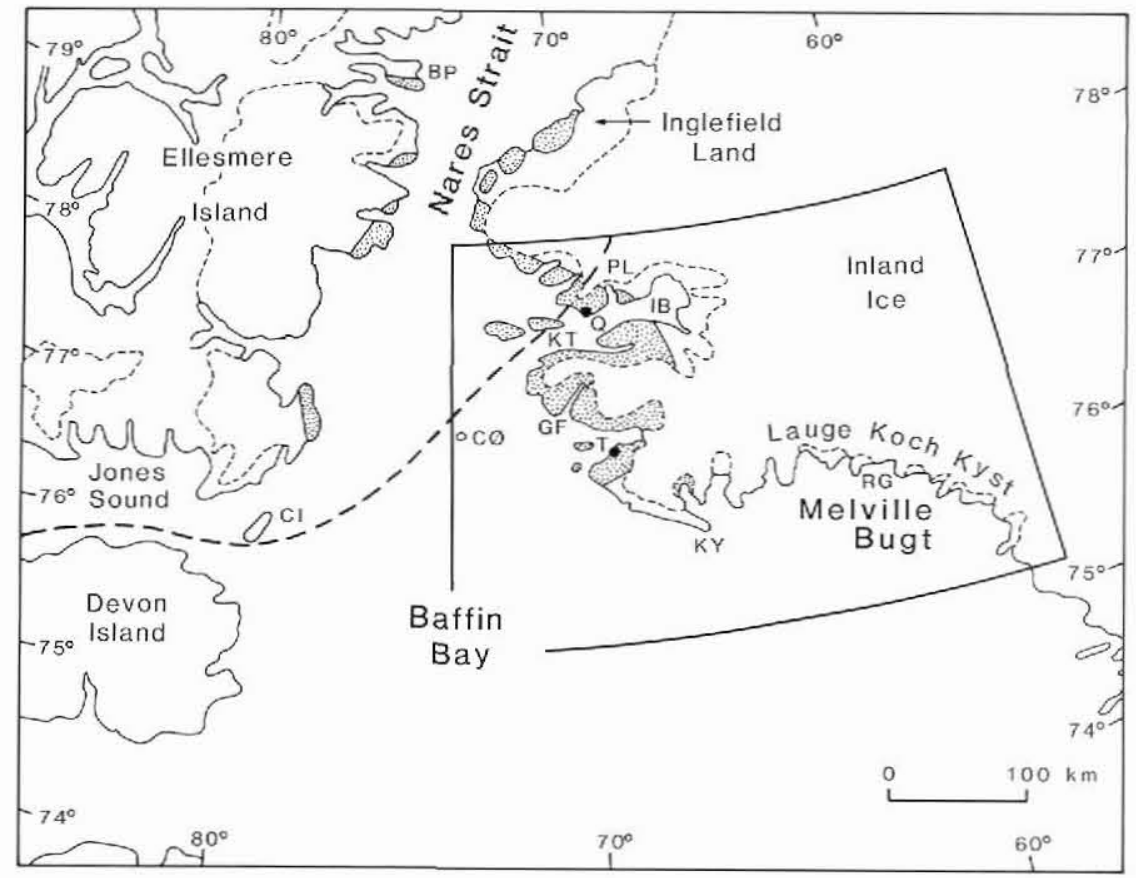

Fig. 2. Map of northern Baffin Bay - southern Nares Strait showing outline of the 1:500 000 Thule map. Shown are the Proterozoic (Neohelikian-Hadrynian) Thule Supergroup (stippled symbol) and the boundary (dashed line) between Archaean (Rae) hinterland to the south and the Proterozoic (Aphebian, ?Thelon) magmatic belt to the north. $\mathrm{BP}$ - Bache Peninsula, CI - Coburg Island, CØ - Carey Øer, GF - Granville Fjord, IB - Inglefield Bredning. KT - Kap Trautwine, KY - Kap York, PL Prudhoe Land, Q - Qaanaaq/ Thule, RG - Rink Gletscher, TThule Air Base/Pituffik.

\section{Proterozoic Thule Basin}

The Thule map sheet covers the main outcrops of the Thule Basin with its sedimentary and igneous sequence - the Thule Supergroup. Marginal outcrops occur farther north in Inglefield Land while the western part of the basin is preserved in coastal Ellesmere Island, Canada (Frisch, 1988). Four groups of the Thule Supergroup are portrayed - Nares Strait, Baffin Bay, Dundas, and Narssârssuk Groups - but where convenient, stratal subdivision down to formation level is shown. The age of the Thule Supergroup is based on microfossil evidence and on isotopic dating of extrusive and intrusive basaltic rocks. The Nares Strait Group representing the basal part contains strata as old as Neohelikian (at least $1220 \mathrm{Ma}$ ) while the youngest strata of the Narssârssuk Group may be as young as late Hadrynian ( $700-650$ Ma).

\section{Proterozoic basic magmatism}

An attempt has been made to distinguish between the main periods of late Proterozoic basaltic magmatism that are seen on the map mainly as dykes and sills. Three main age groups have been recognised: Palaeohelikian (dykes), Neohelikian (mainly extrusives and sills) and Hadrynian (sills and dykes). The Thule map covers the northern extent of the longest dyke swarm in Greenland - the Melville Bugt dyke swarm. This swarm of NW dykes can be traced for over $1000 \mathrm{~km}$ along the western coast of Greenland (Nielsen, 1990). It pre-dates the Thule Supergroup and in the map area has given whole-rock K/Ar ages between 1667 and $1450 \mathrm{Ma}$.

The other prominent dyke swarm post-dates the Thule Supergroup (Fig. 3). This is WNW trending and has given whole-rock $\mathrm{K} / \mathrm{Ar}$ ages in the range 675-630 Ma. Slightly earlier Hadrynian magmatism forms conspicuous sills, including the Steensby Land sill complex that has given whole-rock K/Ar ages between 707 and $660 \mathrm{Ma}$. Neohelikian magmatism was contemporaneous with the deposition of the lower Thule Supergroup and is seen in the form of volcanics (Fig. 3) and minor intrusions.

\section{Quaternary geology}

Presentation of the surficial geology differs from other 1:500 000 sheets issued by GGU in that differentiation of the Quaternary deposits is made. Five categories are recognised: (1) historic moraine, (2) till and glaciofluvial deposits, (3) alluvium and deltaic deposits, (4) marine deposits, and (5) ice margin deposits and medial moraine. Marine silts occur as high as $60 \mathrm{~m}$ above present sea level, an altitude that is regarded as the Holocene marine limit.

\section{Meteorites}

The Cape York meteorite shower, thought to have reached Earth more than 2000 years ago (Buchwald \& 


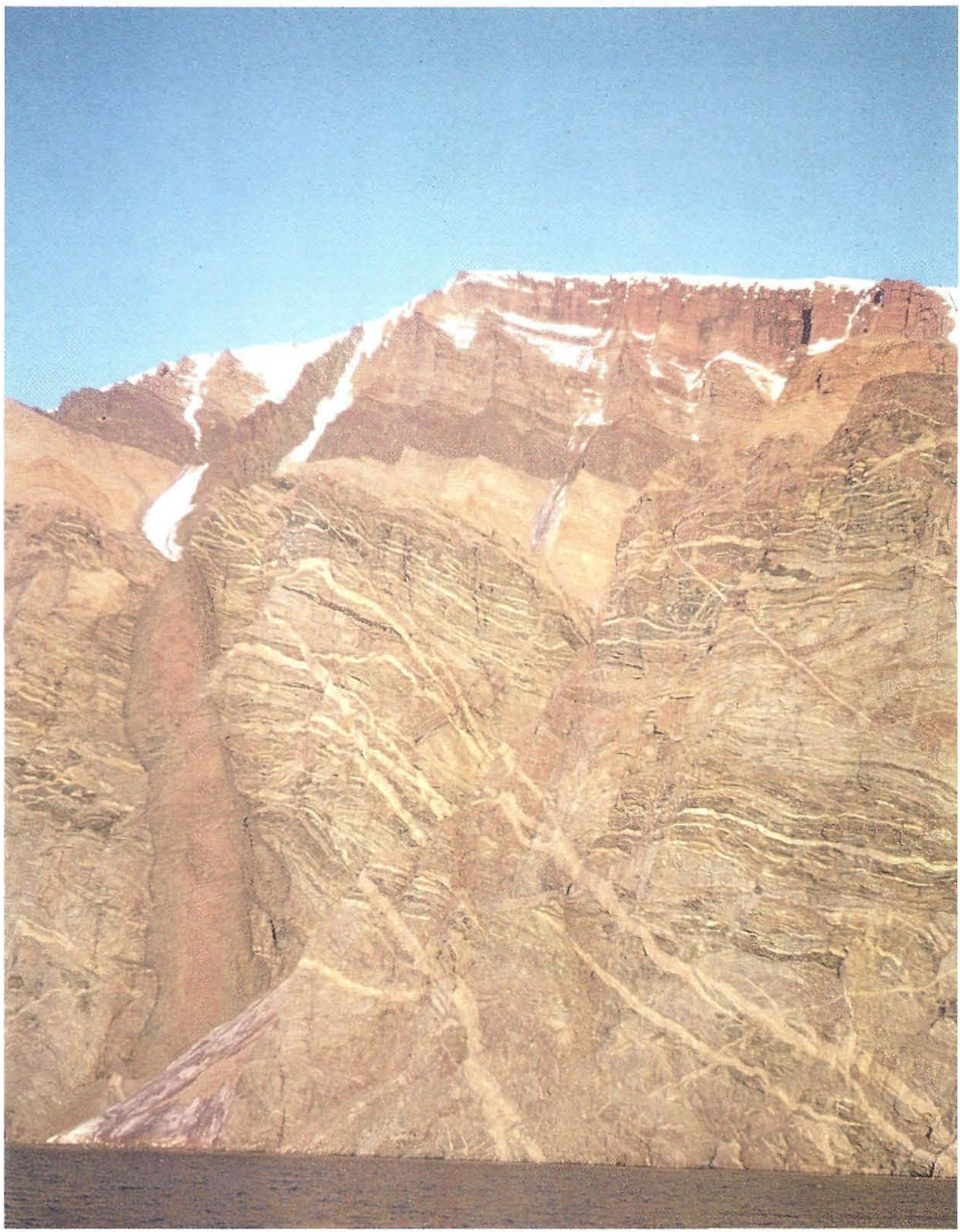

Fig. 3. The two Precambrian provinces represented on the Thule map: unmetamorphosed Proterozoic (Neohelikian-Hadrynian) Thule Basin strata (Thule Supergroup) overlying the crystalline rocks of the Precambrian shield (Archaean-Aphebian). The dark unit near the base of the Thule Supergroup is a formation of Neohelikian basaltic volcanic rocks. Entire section is cut by a Hadrynian basic dyke. Sea cliffs of Kap Trautwine, height about $900 \mathrm{~m}$. Photo: P. R. Dawes. 
Thule Supergroup

Prudhoe Land Granulite Complex

Melville Bugt Orthogneiss Complex

Kap York Meta-igneous Complex

Smithson Bjerge Magmatic Association

Thule Mixed-gneiss Complex
Late Proterozoic

THULE BASIN

Early- Middle Proterozoic

Archaean
PRECAMBRIAN

SHIELD

Fig. 4. Main Precambrian rock subdivisions shown on the Thule map.

Mosdal, 1985), is indicated by location of those discovery sites that can be positively identified. The eight sites shown delimit a NW-SE elongated fall pattern almost $100 \mathrm{~km}$ long.

\section{Economic geology}

The map covers two publicised economic mineral occurrences: heavy mineral sands (mainly ilmenite) on active and uplifted beaches in the central Thule district (Dawes, 1989) and a regional belt of banded iron formation traceable for $350 \mathrm{~km}$ throughout the gneiss terrain of Melville Bugt (Dawes \& Frisch, 1981). These deposits and other economic mineral occurrences, including copper-bearing and iron sulphide mineralisations as well as materials for local domestic industries, viz. soapstone and agate, are shown by symbols.

The Thule Basin shows many similarities in setting, structure and lithology to the coeval rift-related Borden Basin of Bylot Island and northern Baffin Island described by Jackson \& Iannelli (1981). The present exploitation of a carbonate-hosted lead-zinc mineralisation in the Canadian basin (Nanisivik mine) directs attention to the Thule Basin as an economic target.

\section{Regional geology}

The Thule map sheet covers the eastern coast of northern Baffin Bay. Publication of the map, seen together with the map sheets at 1:250 000 covering the western side of the bay (SE Ellesmere Island and Devon Island) issued by the Geological Survey of Canada (Frisch, 1988), provides a ready basis for the analysis of the regional geology of southern Nares Strait. Most obvious is the correlation of the Thule Supergroup and the definition of the Thule Basin as a major depocenter straddling the seaway (Fig. 2). The northernmost out- crops of the Thule Supergroup occur north of the map sheet boundary in Inglefield Land.

The other major regional structure occurring on both sides of northern Baffin Bay is the boundary between Archaean and Proterozoic crust. It should be noted that the Proterozoic Rinkian mobile belt, defined initially in the region between $69^{\circ}$ and $74^{\circ}$ in western Greenland (Escher \& Pulvertaft, 1976) and characterised by a distinctive structural style, does not continue north beyond Melville Bugt as inferred in several regional accounts (for discussion see Dawes, 1988; Grocott \& Pulvertaft, 1990). However, this does not exclude the possibility of the presence of Proterozoic supracrustal rocks within the Archaean block that makes up the region from $75^{\circ}$ to about $77^{\circ} 30^{\prime} \mathrm{N}$.

On the western side of Baffin Bay the boundary between the Archaean hinterland (the Rae Province in the terminology of Hoffman, 1989) and a belt of Proterozoic magmatism to the north-west (possible continuation of the Thelon province, see below), is well defined by both field relationships and isotopic dating (Frisch, 1988; Frisch \& Hunt, 1988; Fig. 2). The Proterozoic intrusive rocks and associated orthogneisses are also present in Greenland and they form a distinctive regional province that has been named the EllesmereInglefield belt after its distribution in south-east Ellesmere Island and Inglefield Land. This is characterised by magmatic intrusives isotopically dated at $2.0-1.8 \mathrm{Ga}$. The Etah Meta-igneous Complex, a very obvious link between Ellesmere Island and Greenland (Frisch, 1981, 1988; Frisch \& Dawes, 1982), is part of this belt. The Ellesmere-Inglefield belt may represent the north-easterly continuation of the Thelon orogen which is described by Hoffman (1989) as a deeply-eroded collision zone separating the Archaean Slave and Rae Provinces. Hoffman shows this orogen crossing the Canadian Arctic Archipelago farther to the west, a position that ap- 
pears to be based on speculation (T. Frisch, personal communication, 1990). In any case the terrain boundary delineated in the Jones Sound area on the western side of Baffin Bay can be picked up in Prudhoe Land in the northern part of the Thule district. Unfortunately, however, in Greenland its character is not easy to determine since it is for the most part covered by Thule Basin deposits and is exposed only in heavily ice-covered and nunatak country (Fig. 2).

\section{References}

Buchwald, V.F. \& Mosdal, G. 1985: Meteoritic iron, telluric iron and wrought iron in Greenland. Meddr Grønland Man \& Society 9,49 pp.

Davies, W. E., Krinsley, D. B. \& Nicol, A. H. 1963: Geology of the North Star Bugt area, Northwest Greenland. Meddr Grønland 162(12), $68 \mathrm{pp}$.

Dawes, P. R. 1988: Etah meta-igneous complex and the Wulff structure: Proterozoic magmatism and deformation in Inglefield Land, North-West Greenland. Rapp. Grønlands geol. Unders. 139, 24 pp.

Dawes, P. R. 1989: The Thule black sand province, NorthWest Greenland: investigation, status and potential. Open File Ser. Grønlands geol. Unders. 89/4, 17 pp.

Dawes, P. R. 1991: Geological map of Greenland 1:500 000, sheet 5, Thule. Copenhagen: Grønlands Geologiske Undersøgelse.

Dawes, P. R. \& Frisch, T. 1981: Geological reconnaissance of the Greenland Shield in Melville Bugt, North-West Greenland. Rapp. Grønlands geol. Unders. 105, 18-26.

Dawes, P. R., Larsen, O. \& Kalsbeek, F. 1988: Archaean and Proterozoic crust in North-West Greenland: evidence from Rb-Sr whole-rock age determinations. Can. J. Earth Sci. 25, 1365-1373.

Escher, A. \& Pulvertaft, T. C. R. 1976: Rinkian mobile belt of West Greenland. In Escher, A. \& Watt, W. S. (ed.) Geology of Greenland, 104-119. Copenhagen: Geol. Surv. Greenland.

Fernald, A. T. \& Horowitz, A. S. 1964: Bedrock geology of the Nunatarssuaq area, Northwest Greenland. Meddr Grønland 172(6), $44 \mathrm{pp}$.
Frisch, T. 1981: Comparative note on the Precambrian basement of southern Inglefield Land and eastern Ellesmere Island. Rapp. Grønlands geol. Unders. 105, 14-18.

Frisch, T. 1988: Reconnaissance geology of the Precambrian Shield of Ellesmere, Devon and Coburg islands, Canadian Arctic Archipelago. Mem. geol. Surv. Can. 409, 102 pp.

Frisch, T. \& Dawes, P. R. 1982: The Precambrian shield of northernmost Baffin Bay: correlation across Baffin Bay. In Dawes, P. R. \& Kerr, J. W. (ed.) Nares Strait and the drift of Greenland: a conflict in plate tectonics. Meddr Grønland Geosci. 8, 79-88.

Frisch, T. \& Hunt, P. A. 1988: U-Pb zircon and monazite ages from the Precambrian Shield of Ellesmere and Devon islands, Arctic Archipelago. Pap. geol. Surv. Can. 88-2, 117125.

Grocott, J. \& Pulvertaft, T. C. R. 1990: The Early Proterozoic Rinkian Belt of central West Greenland. In Lewry, J. F. \& Stauffer, M. R. (ed.) The Early Proterozoic Trans-Hudson Orogen of North America. Spec. Pap. geol. Ass. Can. 37, 443-463.

Henriksen, N. \& Higgins, A. K. 1991: The North Greenland Project. In Peel, J. S. \& Sønderholm, M. (ed.) Sedimentary basins of North Greenland. Bull. Grønlands geol. Unders. 160, 9-24.

Hoffman, P. F. 1989: Precambrian geology and tectonic history of North America. In Bally, A. W. \& Palmer, A. R. (ed.) The geology of North America: an overview. Decade of North American Geology A, 447-512. Boulder: Geological Society of America.

Jackson, G. \& Iannelli, T. R. 1981: Rift-related cyclic sedimentation in the Neohelikian Borden Basin, northern Baffin Island. In Campbell, F. H. A. (ed.) Proterozoic basins of Canada. Pap. geol. Surv. Can. 81-10, 269-302.

Nielsen, T. F. D. 1990: Melville Bugt dyke swarm: a major 1645 Ma alkaline magmatic event in West Greenland. In Parker, A. J., Rickwood, P. C. \& Tucker, D. H. (ed.) Mafic dykes and emplacement mechanisms, 497-505. Rotterdam: A. A. Balkema.

Nutman, A. P. 1984: Precambrian gneisses and intrusive anorthosite of Smithson Bjerge, Thule district, North-West Greenland. Rapp. Grønlands geol. Unders. 119, 31 pp.

P. R. D., Geological Survey of Greenland, Copenhagen. 